Article

\title{
Increased IL-2 and Reduced TGF- $\beta$ Upon T-Cell Stimulation are Associated with GM-CSF Upregulation in Multiple Immune Cell Types in Multiple Sclerosis
}

\author{
Jehan Aram 1, Nanci Frakich 1, Elena Morandi 1,2, Mohammed Alrouji 1,3 (D, \\ Amal Samaraweera ${ }^{1,4,5}$, David Onion ${ }^{6}$, Ian Spendlove ${ }^{7}$, Sergio L. Colombo ${ }^{8}$ (D), \\ Radu Tanasescu ${ }^{1,4,9}$, Bruno Gran ${ }^{1,4}$ (D) and Cris S. Constantinescu $1,4, *$ (D) \\ 1 Division of Clinical Neuroscience, Section of Clinical Neurology, University of Nottingham, \\ Nottingham NG7 2UH, UK; jehan_ph_tarzean@yahoo.com (J.A.); nanci.frakich@nottingham.ac.uk (N.F.); \\ elena.morandi@inserm.fr (E.M.); malrouji@gmail.com (M.A.); amal.samaraweera@doctors.org.uk (A.S.); \\ r.tanasescu@nottingham.ac.uk (R.T.); bruno.gran@nuh.nhs.uk (B.G.) \\ 2 Inserm, Centre de Physiopathologie de Toulouse Purpan (CPTP), 31300 Toulouse, France \\ 3 College of Applied Medical Sciences, Shaqra University, Shaqra 11961, Saudi Arabia \\ 4 Department of Neurology, Nottingham University Hospitals NHS Trust, Nottingham NG7 2UH, UK \\ 5 Royal Victoria Infirmary, Newcastle upon Tyne NHS Foundation Trust, Newcastle NE1 4LP, UK \\ 6 Ex vivo Cancer Pharmacology Centre of Excellence, University of Nottingham, Nottingham NG7 2UH, UK; \\ David.onion@nottingham.ac.uk \\ 7 Academic Clinical Oncology, University of Nottingham, Nottingham NG7 2UH, UK; \\ ian.spendlove@nottingham.ac.uk \\ 8 Centre for Diabetes, Chronic Diseases, and Ageing, School of Science and Technology, Nottingham Trent \\ University, Nottingham NG11 8NS, UK; Sergio.colombo@ntu.ac.uk \\ 9 Department of Neurology, Colentina Hospital, University of Medicine and Pharmacy Carol Davila, \\ Bucharest 021172, Romania \\ * Correspondence: cris.constantinescu@nottingham.ac.uk
}

Received: 28 June 2020; Accepted: 16 July 2020; Published: 18 July 2020

\begin{abstract}
Granulocyte macrophage colony stimulating factor (GM-CSF) is a pro-inflammatory cytokine produced by immune cells. Recent evidence suggests that GM-CSF plays an important role in multiple sclerosis (MS) pathogenesis. We investigated the expression and regulation of GM-CSF in different immune cells in MS. We also investigated the differentiation and frequency of GM-CSF-producing Th cells that do not co-express interferon (IFN)- $\gamma$ or interleukin-17 (IL-17) (Th-GM cells) in MS. We found a significant increase in the percentage of GM-CSF-expressing Th cells, Th1 cells, Th-GM cells, cytotoxic T (Tc) cells, monocytes, natural killer (NK) cells, and B cells in PBMC from MS patients stimulated with $T$ cell stimuli. Stimulated PBMC culture supernatants from MS patients contained significantly higher levels of IL-2, IL-12, IL-1 $\beta$, and GM-CSF and significantly lower levels of transforming growth factor (TGF-) $\beta$. Blocking IL-2 reduced the frequency of Th-GM cells in PBMC from MS patients. The frequency of Th-GM cells differentiated in vitro from naïve $\mathrm{CD}^{+}{ }^{+} \mathrm{T}$ cells was significantly higher in MS patients and was further increased in MS with IL-2 stimulation. These findings suggest that all main immune cell subsets produce more GM-CSF in MS after in vitro stimulation, which is associated with defective TGF- $\beta$ and increased IL-2 and IL-12 production. Th-GM cells are increased in MS. GM-CSF may be a potential therapeutic target in MS.
\end{abstract}

Keywords: GM-CSF; human; MS/EAE; PBMC; T cells; B cells; NK cells; monocytes 


\section{Introduction}

Multiple sclerosis (MS) is an immune-mediated inflammatory disease of the central nervous system (CNS) characterised by inflammation, demyelination, axonal damage, and gliosis [1]. The exact underlying causes of MS are still unknown [2,3]. In MS, there is an imbalance between pro-inflammatory and the anti-inflammatory factors, favouring the former. Granulocyte macrophage colony stimulating factor (GM-CSF) is a pro-inflammatory cytokine that acts on mature myeloid cells to activate them [4-6]. It is also a haematopoietic growth factor that stimulates the formation of granulocytes and macrophages (mature myeloid cells) from precursor cells in the bone marrow [7]. It is expressed by many cell types, including haematopoietic lineage cells. GM-CSF receptor (GMR) is expressed by many cell types, including monocytes, macrophages, antigen presenting cells (APCs), neurons, astrocytes, and oligodendrocytes. This suggests that GM-CSF is involved in physiological regulation of these cells [8].

The important role of GM-CSF in inflammatory demyelination has been demonstrated in studies of the experimental autoimmune encephalomyelitis (EAE) model of MS. Th cells (whether Th1 or Th17) lacking GM-CSF are unable to transfer EAE, GM-CSF-deficient mice are resistant to EAE induction, and GM-CSF antibodies prevent the onset of EAE [9-13]. Moreover, overexpression of GM-CSF leads to more severe EAE by increasing the influx of inflammatory cells into the CNS [14]. GM-CSF was also found to enhance long-term disability in EAE [15]. In addition, myelin peptide-reactive Th1 and Th17 cells that lack GM-CSF failed to transfer EAE [11,12]. A recent study has shown a distinct pathogenic GM-CSF-producing Th cells in EAE [16]. Another study found a distinct Th subtype that mainly express GM-CSF and IL-3 and is essential for EAE pathogenesis [17]. In MS, the role of GM-CSF has also been demonstrated, and the evidence is strengthened by recent studies. GM-CSF levels in the cerebrospinal fluid (CSF) were shown to be elevated in the active stage of MS [18]. Recent studies have found that GM-CSF is highly expressed by CD4 and CD8 T cells in the brains of MS patients [19] and that GM-CSF-producing CD4 ${ }^{+}$T cells are increased in the cerebrospinal fluid (CSF) of MS patients [20]. The GM-CSF receptor is highly expressed in MS lesions [21]. Our collaborators and we identified the role of MS-associated IL-2R polymorphism in the induction by IL-2 of GM-CSF in Th cells [22]. Another recent study has shown a distinct GM-CSF-only producing the Th cell subtype (ThGM) in the CSF of MS patients [23]. Importantly, a seminal study shows that such GM-CSFs predominantly producing Th cells are $\mathrm{CXCR} 4^{+}$, have pathogenic features in MS, and expand the spectrum of immune cells overexpressing GM-CSF in MS beyond T and B cells [24]. The mechanisms of induction and in particular the deficit of regulatory factors that allow GM-CSF upregulation in MS have not been thoroughly studied.

In this study, we investigated GM-CSF expression and regulation in multiple stimulated immune cell subsets in the peripheral blood of people with MS. We show that the percentage of GM-CSF-expressing stimulated peripheral blood mononuclear cells (PBMC) subsets (Th cells, Tc cells, monocytes, natural killer (NK) cells, and B cells) is higher in MS patients when compared to healthy controls (HCs). The frequency of non-Th1 non-Th17 GM-CSF-producing Th cells (Th-GM cells) and of Th1 cells expressing GM-CSF is higher in MS patients. Based on the percentage of each immune cell subset expressing GM-CSF, Th and Tc cells are the main GM-CSF producers among the immune cell subsets tested. Blocking IL-2 and IL-12 significantly reduces GM-CSF expression by Tc, NK, and B cells in MS patients but not in these cell types for HCs, implicating IL-2 and IL-12 as important stimulatory pathways for GM-CSF in MS. Unlike the study by Galli et al. [24] we stimulate mixed PBMC populations with T cell-specific stimuli to determine if these stimuli affect GM-CSF expression in $\mathrm{T}$ and non- $\mathrm{T}$ cells and, thus, indicate a T cell-derived effect in non- $\mathrm{T}$ cells. 


\section{Subjects and Methods}

\subsection{Subjects}

All sample collection and experimental work were approved by the Nottingham Research Ethics Committee 2 (08/H0408/167; approved 05/01/2009), and the study was conducted in accordance with the guidelines of the World Medical Association's Declaration of Helsinki (most recent revision). All participants (healthy controls (HCs) and MS patients) signed an informed consent before participation. All participating patients had untreated relapsing MS (relapsing-remitting MS (RRMS) and secondary progressive MS (SPMS) in relapsing stage; RRMS, $n=38$; SPMS $n=9$ ). Patients were $\geq 18$ years old, had Expanded Disability Status Scale (EDSS) scores $\leq 6.5$, and were relapse free for at least 1 month before recruitment. Exclusion criteria were being pregnant or breast-feeding, having serious infections or other conditions (hepatic, renal, psychiatric, addiction, pulmonary, cardiac, or malignancy), having had a vaccination within 6 months of blood collection, having treatment with immuno-modulatory or immunosuppressive therapies within 1-12 months (depending on the type of therapy) of recruitment, or having a coexistent disease that needs to be treated with such medications. Some of the patients recruited were previously treated with interferon (IFN)- $\beta$, daclizumab, copaxone, or fingolimod and had discontinued immunomodulatory therapy for $\geq 2$ months before participation mainly in anticipation of treatment switch. In the patients recruited, there was a gap of a minimum of 3 months between last clinical relapse and time of participation.

\subsection{Cell Culture and Stimulation}

PBMCs were isolated by standard density gradient centrifugation protocol using Histopaque-1077 (Sigma-Aldrich, St. Louis, MO, USA). Fresh or thawed PBMC $\left(1 \times 10^{6}\right.$ cells/well) were cultured in 24-well plates with RPMI medium containing 10\% fetal calf serum (FCS), 100 units/mL of penicillin, $0.1 \mathrm{mg} / \mathrm{mL}$ of streptomycin, and $2 \mathrm{mM}$ of glutamine (all from Sigma-Aldrich). Cells were either left unstimulated or stimulated with soluble anti-CD3 and anti-CD28 antibodies $(1 \mu \mathrm{g} / \mathrm{mL}$ each; BD Biosciences, Franklin Lakes, NJ, USA) and incubated for 5 days in a $37^{\circ} \mathrm{C}$ incubator with humidified atmosphere and $5 \% \mathrm{CO}_{2}$. Individual experiments did not mix fresh and frozen cells.

For cytokine blocking, cells were treated with one or more of the following human antibodies or antagonists (all from R\&D Systems) to reach a final concentration of $10 \mu \mathrm{g} / \mathrm{mL}$ each: anti-IL-2 and anti-IL-2R-alpha, anti-IL-12p70, anti-IL-12/23p40, anti-IL-1 $\beta$ and recombinant human IL-1RA, and mouse IgG1 isotype control.

\subsection{NK Cell Isolation and Stimulation}

After PBMC isolation, NK cells were magnetically isolated using an NK isolation kit (Miltenyi Biotec, Bergisch Gladbach, Germany) via negative selection following the manufacturer's instructions. NK cells were counted and checked for purity (CD3- ${ }^{-} \mathrm{CD}^{+} \geq 90 \%$ ). They were resuspended in RPMI medium with 15\% FCS, 100 units/mL of penicillin, $0.1 \mathrm{mg} / \mathrm{mL}$ of streptomycin, and $2 \mathrm{mM}$ of glutamine and distributed in a 24 -well plate $\left(1 \times 10^{5}\right.$ cells/well). NK cells were either left unstimulated or stimulated with one of the following: rhIL-15 (100 ng/mL) (R\&D Systems) + rhIL-1 $\beta$ (10 ng/mL) (Peprotech, Cranbury, NJ, USA), rhIL-15 (100 ng/mL) + rhIL-18 (100 ng/mL) (R\&D Systems), and rhIL-2 (10 ng/mL) + rhIL-12 (10 ng/mL) (Peprotech). Cells were incubated for 3 days at $37^{\circ} \mathrm{C}$ with $5 \% \mathrm{CO}_{2}$.

\subsection{Nä̈ve CD4 T Cell Isolation and Stimulation for Identification of Th-GM Cells}

After PBMC isolation, naïve CD4 T cells were isolated using magnetic Naïve CD4 ${ }^{+}$T Cell Isolation Kit II (Miltenyi Biotec) via negative selection, following the manufacturer's instructions. They were counted and checked for purity $\left(\geq 90 \% \mathrm{CD}^{+} \mathrm{CD} 4 \mathrm{RA}^{+}\right)$. Naïve CD4 T cells were distributed in a 24-well plate and divided into five wells $\left(1 \times 10^{6}\right.$ cells/well $)$ left either unstimulated or stimulated with soluble anti-CD3 (3 $\mathrm{gg} / \mathrm{mL})$ and anti-CD28 $(1 \mu \mathrm{g} / \mathrm{mL}$, both from BD Biosciences). Stimulated cells 
were treated with or without any of the following: rhIL-2 $(50 \mathrm{ng} / \mathrm{mL})$, rhIL-7 $(20 \mathrm{ng} / \mathrm{mL})$, or their combination (both from Peprotech). Cells were incubated for 7 days at $37^{\circ} \mathrm{C}$ with $5 \% \mathrm{CO}_{2}$.

\subsection{Cell Identification and Analysis by Flow Cytometry}

Before staining protocols, cells were restimulated for the last $5 \mathrm{~h}$ with phorbol myristate acetate (PMA, $50 \mathrm{ng} / \mathrm{mL}$, Sigma) and ionomycin (I, $0.5 \mu \mathrm{g} / \mathrm{mL}$, Sigma) in the presence of brefeldin A $(10 \mu \mathrm{g} / \mathrm{mL}$, Sigma). Cultured cell suspensions were placed in fluorescence activated cell sorter (FACS) tubes, including the negative control, single colour controls, and fluorescence minus one (FMO) controls. They were centrifuged ( $300 \times \mathrm{RCF}$ for $5 \mathrm{~min}$ ), washed once with phosphate-buffered saline (PBS) ( $1 \mathrm{~mL}$, Sigma), and then resuspended in $1 \mathrm{~mL}$ PBS. They were then stained with dead cell stain (near IR 1:1000, Invitrogen, Waltham, MA, USA). Cells were left for $20 \mathrm{~min}$ at room temperature in the dark, washed once in FACS buffer (PBS + 2\% FCS), and fixed by adding $0.25 \mathrm{~mL}$ of Fix/Perm solution (BD Biosciences) for $20 \mathrm{~min}$, keeping them at $4{ }^{\circ} \mathrm{C}$. After fixation, cells were washed twice with perm/wash solution $1 \times$ (BD Biosciences). Surface and intracellular staining were performed afterwards using the following antihuman antibodies: CD3-ECD (UCHT1, Beckman Coulter, Brea, CA, USA), CD8-PeCy-7 (SFCI21Thy2D3, Beckman Coulter), CD8-BV785 (RPA-T8, BioLegend, San Diego, CA, USA), CD56-PE (HCD56, BioLegend), CD56-BV605 (NCAM16.2, BD Biosciences), CD14-FITC (HCD14, BioLegend), CD20-PeCy7 (2H7, BioLegend), CD116-APC (REA211, Miltenyi Biotec), GM-CSF-Efluor ${ }^{\circledR}$ 660 (GM2F3, eBioscience, Waltham, MA, USA), GM-CSF-BV421 (BVD2-21C11, BD Biosciences), IL-3-APC (BVD3-1F9, Miltenyi Biotec), IL-17-PE (EBio64CAP17, eBioscience), and IFN- $\gamma$-FITC (45.15, Beckman Coulter). Cells were incubated for $30 \mathrm{~min}$ at $4{ }^{\circ} \mathrm{C}$, then washed once with perm/wash $1 \times(1 \mathrm{~mL})$ and once with FACS buffer $(1 \mathrm{~mL})$, and finally resuspended in $0.3 \mathrm{~mL}$ fixation buffer (BD Biosciences). Cells were analysed on Beckman Coulter Mo-Flo XDP. Typically, a pilot experiment was run on 2-3 samples each from MS patients and controls (where more aliquots were available), validated in a second set of samples of similar size, and then repeated in all samples tested at the same time and, where possible, with duplicate or triplicate measurements per sample.

\subsection{Cytokine Determination by Multiplex Bead Assay and ELISA}

After fresh PBMC isolation and stimulation for 5 days with anti-CD3/anti-CD28, $0.5 \mathrm{~mL}$ culture supernatants were taken from unstimulated and stimulated wells, centrifuged, and stored at $-20{ }^{\circ} \mathrm{C}$ until they were used in multiplex bead assay. The Milliplex ${ }^{\circledR}$ MAP kit (EMD Millipore, Burlington, MA, USA) was used to detect GM-CSF, IFN- $\gamma$, IL-2, IL-7, IL-10, IL-12p70, IL-17, and IL-23. The ProcartaPlex ${ }^{\circledR}$ (Affymetrix eBioscience) kit was used to detect IL-1 $\beta$, IL-6, IL-15, and IL-18. An ELISA kit (BioLegend) was used to detect free active TGF- $\beta 1$. Samples were processed according to manufacturer's protocols. Multiplex samples were run on a Bio-Rad (Bio-Plex ${ }^{\circledR} 200$ System) machine. ELISA samples were run on Benchmark plus microplate reader (Bio-Rad).

\subsection{Statistics and Data Analysis}

Flow cytometry data were analysed using Kaluza 1.5 software (Beckman Coulter). For simplicity, PBMC subtypes were named and analysed based on their canonical function or, for Th-GM, their non-expression of signature Th1 and Th17 cytokines, i.e., helper $\mathrm{T}$ cells $(\mathrm{Th})=\mathrm{CD} 4^{+}$cells; $\quad$ Th $1=\mathrm{CD} 4^{+} \mathrm{IFN}-\gamma^{+}$cells; $\quad$ Th17 $=\mathrm{CD} 4^{+} \mathrm{IL}-17^{+}$cells; Th-GM $=\mathrm{CD}^{+}$IL-17-IFN- $\gamma^{-}$cells; $\quad$ cytotoxic $\mathrm{T}$ cells $(\mathrm{Tc})=\mathrm{CD} 3^{+} \mathrm{CD}^{+}{ }^{+} \mathrm{CD}^{-} 6^{-}$cells; $\mathrm{NK}$ cells $=\mathrm{CD}^{-} \mathrm{CD}^{-} 6^{+}$cells; $\quad \mathrm{B}$ cells $=\mathrm{CD}^{-} \mathrm{CD}^{-} 0^{+}$cells; $\quad$ and monocytes $=\mathrm{CD}^{-} \mathrm{CD}^{-} 4^{+}$cells . Instead of direct staining of cells with $\mathrm{CD}^{+}$, Th cells were identified as $\mathrm{CD}^{+}{ }^{+} \mathrm{CD}^{-}$because of downregulation of CD4 upon stimulation $[25,26]$. Multiplex bead assay data were analysed using Bio-Plex Manager Software. Data were combined, and statistical analysis was performed using GraphPad Prism 6 (GraphPad Software, La Jolla, CA, USA). The type of statistical test applied depends on whether data were normally distributed (measured with D'Agostino and Pearson normality test), and the number of groups was measured, which is specified in each result section. 


\section{Results}

\subsection{Demographic and Clinical Characteristics of Recruited Patients and Control Subjects}

In total, samples were obtained from 47 patients with relapsing MS (38 relapsing remitting, RR, 9 secondary progressive, SP MS): 35 females and 12 males. The mean (SD) age was 43 (12) with a range of 21-67. The mean (SD) EDSS score was 3.3 (1.8), range 1-6.5. The mean (SD) duration of the disease, counting from the onset of the first symptoms, was $7.6(5,2)$, range 9 months-27 years. Clinical and demographic characteristics of the patients are provided in Table S1. A total of 10 healthy controls, 8 females and 2 males, contributed samples for this project. Their mean (SD) age was 43 (13) with a range of $24-58$.

\subsection{Higher Frequency of GM-CSF-Expressing Th1 Cells in PBMC of MS Patients after In Vitro Stimulation}

Using a flow cytometry strategy (Figure 1A), we first examined GM-CSF expression in the most frequently represented subset of Th cells in the PBMC: those expressing IFN- $\gamma$ (Th1 cells, Figure 1A bottom left). We found that the GM-CSF expression was induced significantly in both groups. Moreover, the percentage of GM-CSF-expressing Th1 cells (phenotyped as CD3 ${ }^{+} \mathrm{CD}^{-}$IFN- $\gamma^{+} \mathrm{GM}^{-\mathrm{CSF}}{ }^{+}$cells) out of the total Th1 cells (phenotyped as $\mathrm{CD}^{+} \mathrm{CD} 8^{-} \mathrm{IFN}-\gamma^{+}$cells) was higher in in vitro stimulated PBMS from MS patients when compared to those from HCs (HCs $n$ 10, MS $n=9, p=0.024$ unpaired t-test, Figure 1B, Figure S1). We also compared the expression of GM-CSF in cells co-expressing IL-17 (Th17 cells, Figure 1A bottom right). We found that the GM-CSF expression was induced significantly in both groups; however, no significant differences in GM-CSF expressing Th17 cells (phenotyped as $\mathrm{CD}^{+} \mathrm{CD}^{-} \mathrm{IL}^{-17^{+}} \mathrm{GM}^{-\mathrm{CSF}^{+}}$cells) between MS patients and controls were observed $(p=0.94)$ (Figure 1C). The frequencies of GM-CSF- Th1 or Th17 cells after in vitro stimulation were no different between MS patients and controls (data not shown). Details of cell gating and setting quadrants strategy for the flow cytometry analysis are shown in Figures S2 and S3.

3.3. Higher Percentage of Non-Th1 Non-Th17 Th Cells Expressing GM-CSF (Th-GM Cells) in PBMC of MS Patients after In Vitro Stimulation

We observed the presence of Th cells that expressed GM-CSF but not IFN- $\gamma$ or IL-17 in both HCs and MS patients (Figure $1 \mathrm{E}$ ). We examined the frequency of these cells (CD3 ${ }^{+} \mathrm{CD} 8^{-}$IFN- $\gamma^{-} \mathrm{IL}^{-17^{-}}$ GM-CSF${ }^{+}$) among the overall Th cells and found a statistically significant increase in these cells in PBMC from MS patients after in vitro stimulation when compared to those from HCs (HCs $n=10$, MS patients $n=9, p=0.0009$ unpaired t-test, Figure $1 F)$. This finding indicates that this novel set of Th cells (Th-GM) is upregulated in MS upon stimulation. 


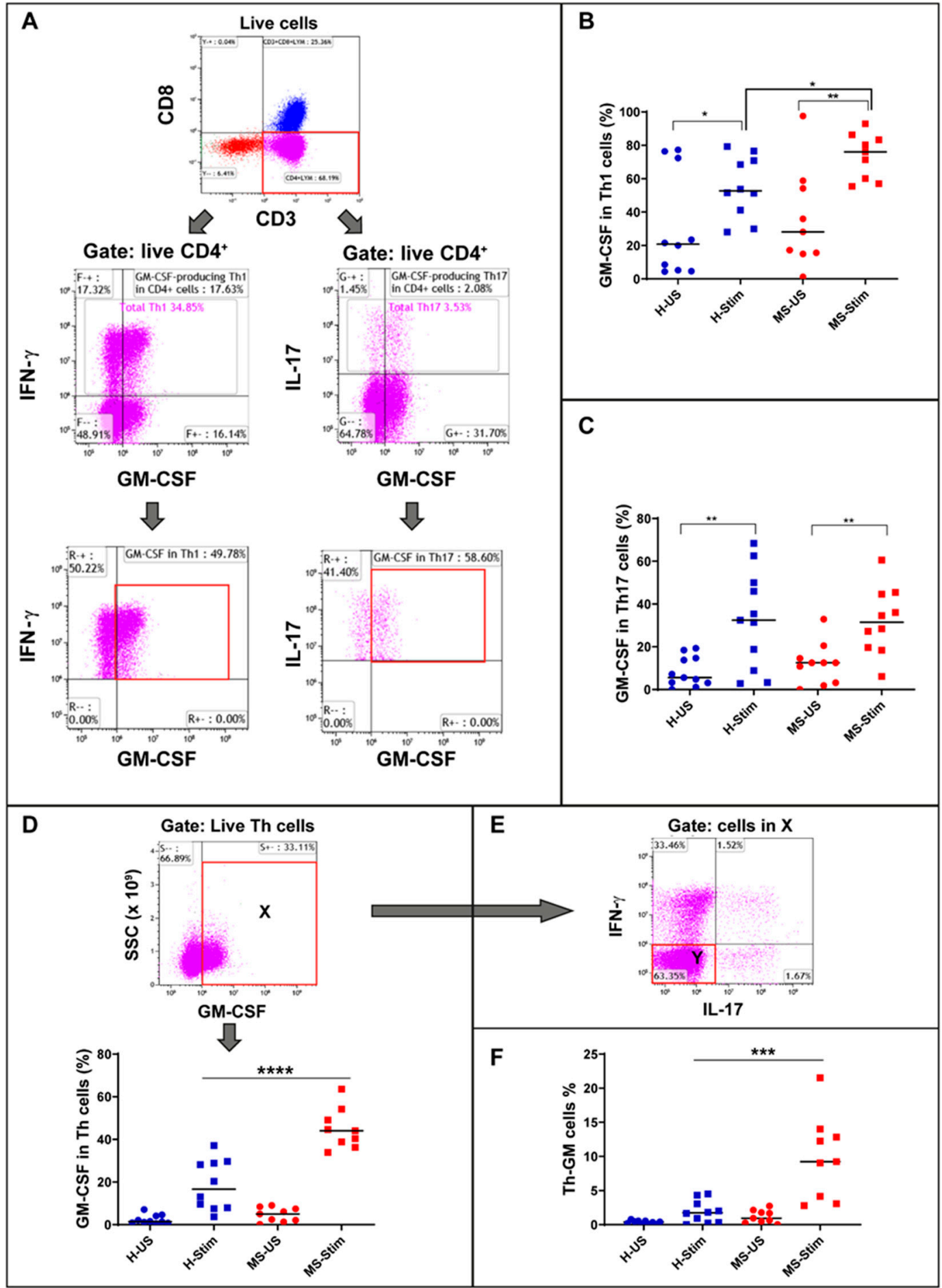

Figure 1. Granulocyte macrophage colony stimulating factor (GM-CSF) expression in Th1, Th17, Th, and Th-GM cells: Frozen isolated peripheral blood mononuclear cells (PBMC) were thawed and stimulated with anti-CD3/anti-CD28 for 5 days and restimulated with phorbol myristate acetate (PMA)/ionomycin (I) in the presence of brefeldin A for the last $5 \mathrm{~h}$. (A) Live CD4 ${ }^{+}$cells were gated for Th1 (middle left panel) and Th17 expression (middle right panel). Then, the corresponding percentage of GM-CSF-producing cells were evaluated (bottom panels). (B) Global analysis of Th1 GM-CSF-producing cells, both in unstimulated and stimulated healthy control and multiple sclerosis (MS) samples: The paired unstimuated/stimulated (US/S)data for each sample are shown in Figure S1. 
(C) Global analysis of Th17 GM-CSF-producing cells, both in unstimulated and stimulated HC and MS samples. (D) Live CD4 ${ }^{+}$(Th) were gated for GM-CSF expression (top panel, population X) and analysed both in unstimulated and stimulated HC and MS samples (lower panel). (E) Population X gated cells were used to identify double negatives for IL17 and IFN- $\gamma$ (population Y). (F) Global analysis of non-Th1, non-Th17 Th cells expressing GM-CSF (Th-GM), both in unstimulated and stimulated $\mathrm{HC}$ and MS samples, was done using the equation Th-GM $(\%)=\mathrm{X} \times \mathrm{Y} \times 100 \%$ (where $\mathrm{X}$ and $\mathrm{Y}$ are expressed as decimal values). H-US: unstimulated cells from healthy controls; H-Stim: stimulated cells from healthy controls; MS-US: unstimulated cells from MS patients; MS-Stim: stimulated cells from MS patients; and SSC: side scattered. Horizontal lines are medians. ${ }^{*} p<0.05 ;{ }^{* *} p<0.01$; ${ }^{* * *} p<0.001$; and ${ }^{* * * *} p<0.0001$.

\subsection{The Frequency of GM-CSF-Expressing Immune Cells Types after In Vitro Stimulation of PBMC Is Higher in $M S$}

We also examined the expression of GM-CSF in overall Th cells (Figure 1D), Tc (CD8 ${ }^{+}$) cells (Figure 2), NK cells (Figure 3), B cells (Figure 4), and monocytes (Figure 5) in the mixed PBMC. After culturing and stimulating PBMC as above, we found a higher frequency of all these cell types expressing GM-CSF in the PBMC from MS patients compared to controls. This shows increased stimulated production of GM-CSF across multiple immune cell lineages in MS. The cells expressing the highest proportion of GM-CSF were Th cells, Tc cells, and monocytes. Although NK cells represented a small proportion of PBMC, a significant proportion expressed GM-CSF (Figure 3). It should be noted that PMA/ionomycin stimulation downregulates CD56 expression [27]; therefore, not all NK cells were detected in this experiment. We also tried to examine natural killer T (NKT) cells, but very few cells were seen in flow cytometry, which did not allow analysis. NK cells and their cytokine expression in MS have not been extensively studied. Our finding of increased GM-CSF expression in NK cells in PBMC of MS patients stimulated with anti-CD3/anti-CD28, a T cell stimulus, suggested that $\mathrm{T}$ cell stimulation upregulates NK cell GM-CSF. We proceeded to determine whether GM-CSF expression is also increased in isolated purified populations of NK cells from people with MS. We chose the stimuli and combination thereof that are known or suspected to be optimal inducers of GM-CSF in NK cells [28]. Isolated and stimulated NK cells (with IL-15 + IL-1 $\beta$, IL-15 + IL-18, or IL-2 + IL-12) did not show any differences in their GM-CSF expression between HCs and MS patients (Figure S5). There was also no difference in the expression of IFN- $\gamma$ between control and MS patient (results not shown) expression. This indicates that the increased GM-CSF in NK cells from MS patients after anti-CD3/anti-CD28 stimulation is dependent on other cell types in PBMC. To investigate such possible stimuli for NK cells, for T cells, and for the other GM-CSF-producing cell types that are responsible for the above findings, we measured in in vitro stimulated PBMC supernatants the concentrations of the relevant cytokines that may regulate GM-CSF expression [11,12,17,20,22,28-33].

3.5. Supernatants of In Vitro Stimulated PBMC from MS Patients Contain Higher Levels of IL-2, IL-12, IL-1 and GM-CSF and Lower TGF- $\beta$ Levels than Those from Healthy Controls

Supernatants collected from cultured and stimulated PBMC were examined to determine the levels of the following cytokines: GM-CSF, IFN- $\gamma$, IL-2, IL-7, IL-10, IL-12p70, IL-17, IL-23, IL-1 $\beta$, IL-6, IL-15, IL-18, and TGF- $\beta 1$. Among those, we found a statistically significant increase in the levels of GM-CSF, IL-2, IL-12, and IL-1 $\beta$ in MS patients when compared to HCs (Mann-Whitney, no correction for multiple measurements as nonindependent, $\mathrm{HC} n=10$; MS $n=14$ : GM-CSF $p=0.026$; IL-2 $p$ $=0.041$; IL-12 $p=0.028$; and IL-1 $\beta p=0.041$; Figure 6). On the other hand, we found a statistically significant decrease in TGF- $\beta 1$ levels in MS patients when compared to HCs (unpaired $t$-test $p=0.0043$, Figure 6). Higher pro-inflammatory cytokine concentrations accompanied by lower levels of the anti-inflammatory cytokine TGF- $\beta$ may explain the dysregulation of GM-CSF in MS. This also suggests that one or more of the above inflammatory cytokines are responsible for the increased expression of GM-CSF (and possibly other inflammatory cytokines) in the PBMC from MS patients. Therefore, 
we performed experiments to block one or more of the cytokines which we found to be increased in MS PBMC supernatants (blocking IL-2, IL-12, IL-2 + IL-12, and IL-1 $\beta$ ), and observed their effects on GM-CSF expression by Th cells, Tc cells, NK cells, and B cells. IL-15 and IL-18 levels were measured but were undetectable in the samples.
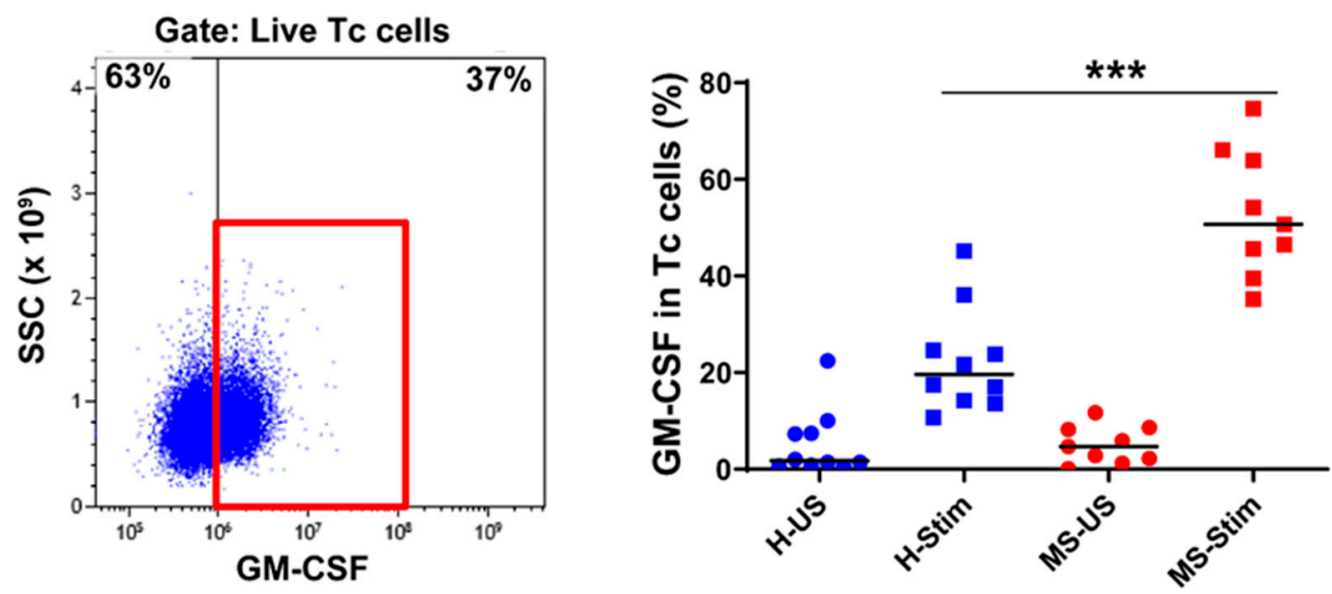

Figure 2. GM-CSF expression in cytotoxic T (Tc) cells: Fresh isolated PBMC were stimulated with anti-CD3/anti-CD28 for 5 days and restimulated with PMA/I in the presence of brefeldin A during the last $5 \mathrm{~h}$. The left panel shows a representative flow cytometry plot analysis in which cells were gated for live Tc cells (full details on the gating strategy can be found in Figure S2). Then, the percentage of GM-CSF-producing cells was counted, and the collective results in healthy controls (H) and MS patients are shown (right panel). US: unstimulated cells; Stim: stimulated. Horizontal lines are medians. *** $p<0.001$.

\section{Gate: Live NK cells}
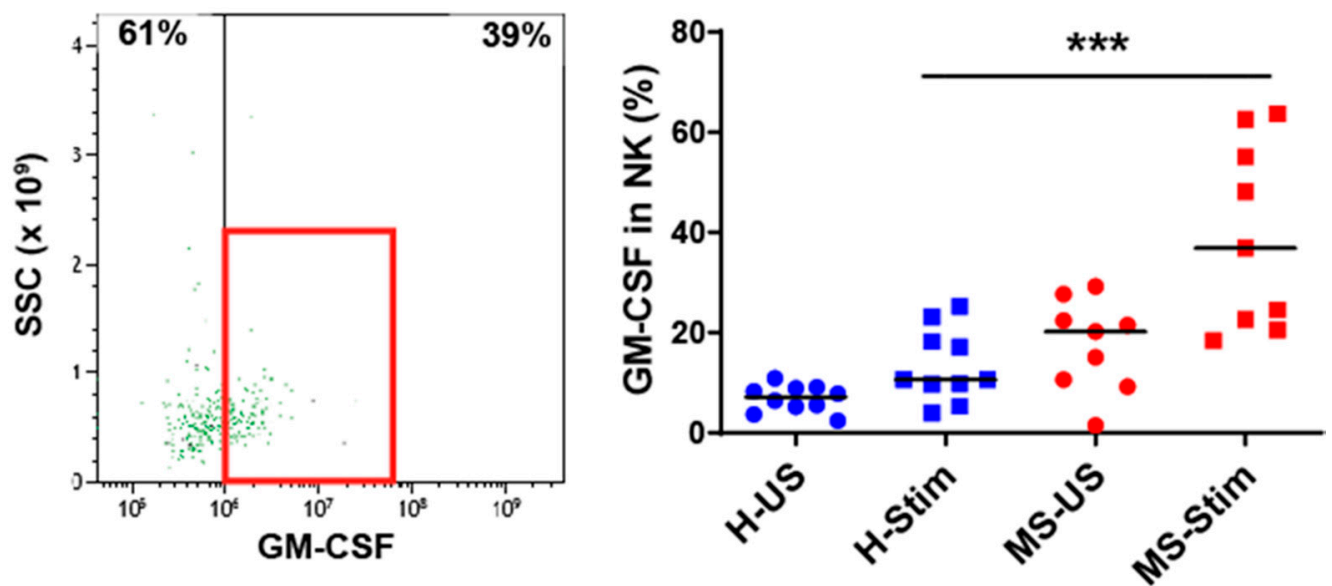

Figure 3. GM-CSF expression in natural killer (NK) cells: Fresh isolated PBMC were stimulated with anti-CD3/anti-CD28 for 5 days and restimulated with PMA/I in the presence of brefeldin A during the last $5 \mathrm{~h}$. The left panel shows a representative flow cytometry analysis in which cells were gated for live NK cells (full details on the gating strategy can be found in Figure S2). Then, the percentage of GM-CSF-producing cells was counted, and the collective results in healthy controls (H) and MS patients are shown (right panel). US: unstimulated cells; Stim: stimulated cells. Horizontal lines are medians. ${ }^{* * *} p<0.001$. 

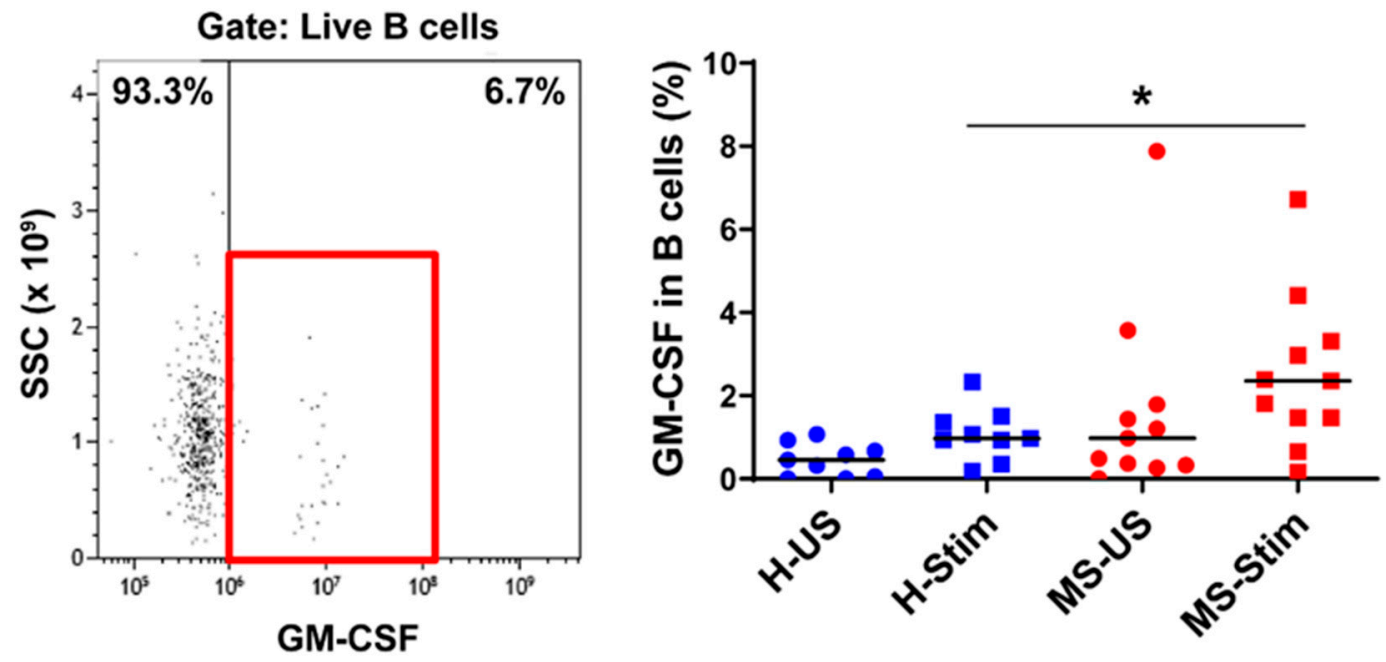

Figure 4. GM-CSF expression in B cells: Frozen isolated PBMC were thawed and stimulated with anti-CD3/anti-CD28 for 5 days and restimulated with PMA/I in the presence of brefeldin A during the last $5 \mathrm{~h}$. The left panel shows a representative flow cytometry analysis in which cells were gated for live B cells (full details on gating in Figure S2). Then, the percentage of GM-CSF-producing cells was counted, and the collective results in healthy controls $(\mathrm{H})$ and MS patients are shown (right panel). US: unstimulated cells; Stim: stimulated cells. Horizontal lines are medians. ${ }^{*} p<0.05$.
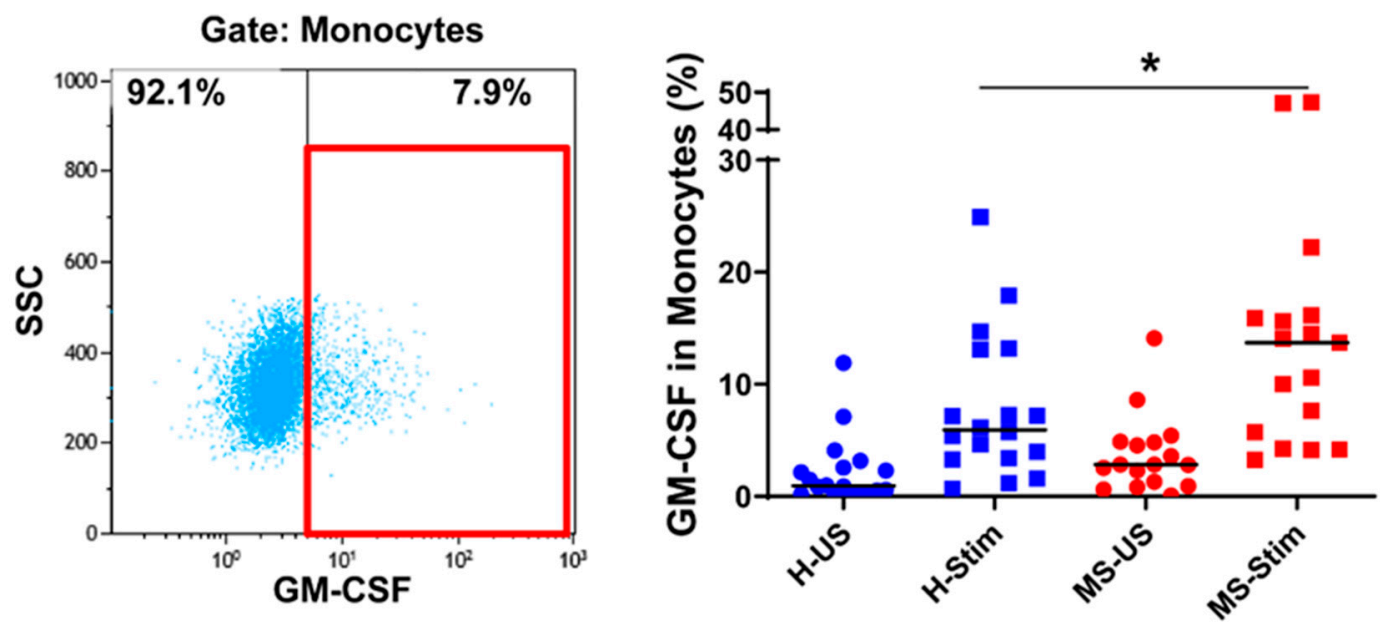

Figure 5. GM-CSF expression in monocytes: Fresh isolated PBMC were stimulated with phorbol dibutyrate (PDB) and ionomycin in the presence of brefeldin A for $16 \mathrm{~h}$. The left panel shows a representative flow cytometry analysis in which cells were gated for monocytes (full details on gating in Figure S4). Then, the percentage of GM-CSF-producing cells was counted, and the collective results in healthy controls $(\mathrm{H})$ and MS patients are shown (right panel). US: unstimulated cells; Stim: stimulated cells. Horizontal lines are medians. ${ }^{*} p<0.05$. 


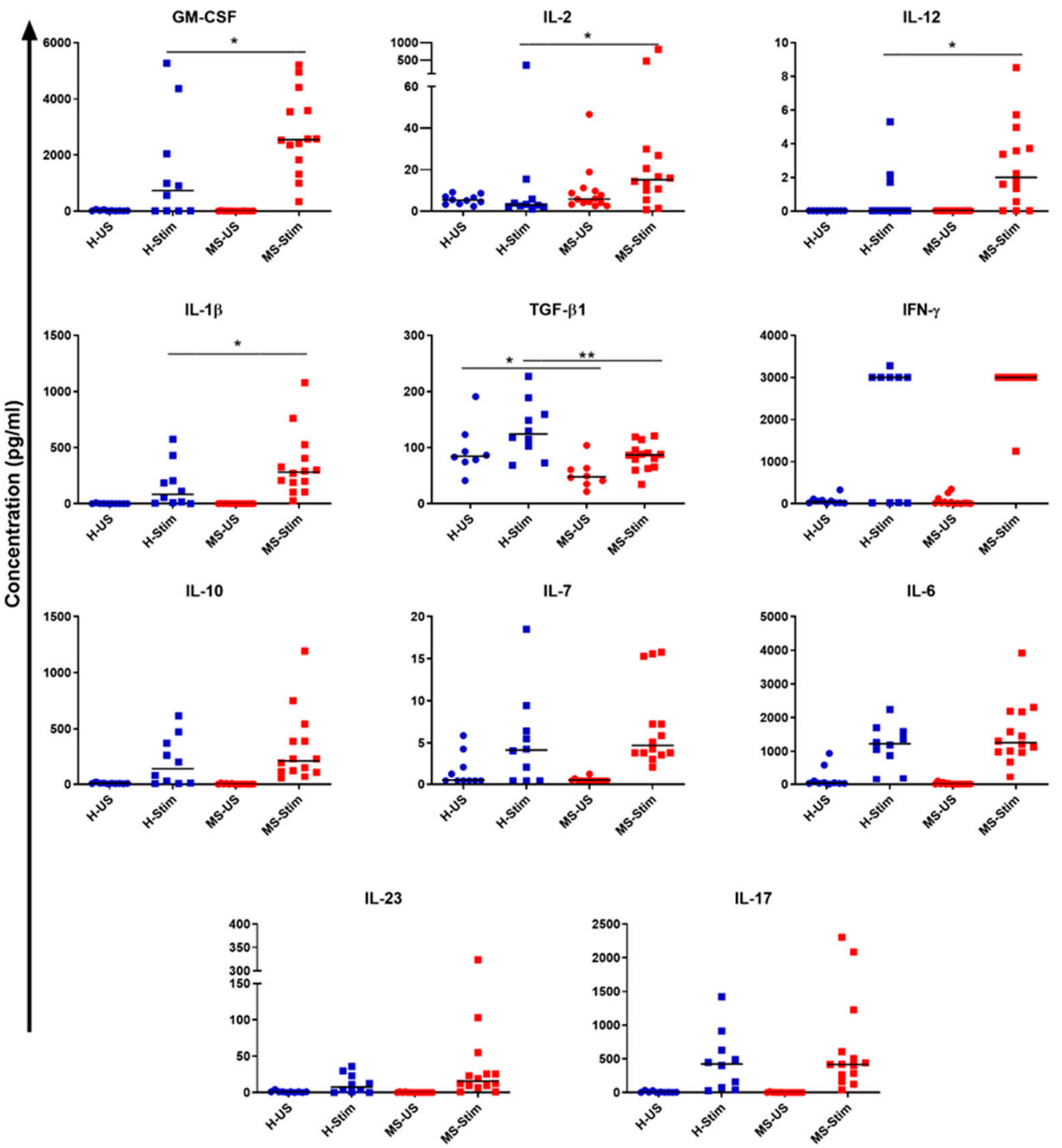

Figure 6. Cytokine profile in PBMC culture supernatants: Fresh isolated PBMC were cultured following anti-CD3/anti-CD28 protocol for 5 days. Culture supernatants were taken on day 5 from healthy controls $(n=10)$ and MS patients $(n=14)$, and profiles of cytokines both in unstimulated and stimulated conditions were determined as explained in the Subjects and Methods section. H-US and MS-US: unstimulated samples from healthy controls $(\mathrm{H})$ and MS patients, respectively. H-Stim and MS-Stim: anti-CD3/anti-CD28-stimulated samples from healthy controls and MS patients, respectively. ${ }^{*} p<0.05$ and ${ }^{* *} p<0.01$. Horizontal lines are medians.

\subsection{Blocking IL-2 In Vitro Reduced the Percentage of Th-GM Cells in Stimulated PBMC from MS Patients}

PBMCs were stimulated with anti-CD3/anti-CD28 in the presence of neutralizing antibodies to the above cytokines or isotype control antibodies. We found that blocking IL-2 (and IL-2 + IL-12) significantly reduced the frequency of Th cells expressing GM-CSF but not co-expressing IFN- $\gamma$ or IL-17 (called Th-GM) in PBMC from MS patients but not in HCs (blocking IL-2: MS $n=9$, Wilcoxon test $p=0.0039$; HC $n=10$, Wilcoxon test $p>0.99$; Figure 7A,B). Blocking only IL-12 did not have any significant effects on these cells in PBMC. Blocking IL-2 + IL-12 had the same effect on Th-GM from MS patients but not on HCs, suggesting that IL-2 plays a key role in these effects (MS $n=8$, Wilcoxon test $p=0.015 ; \mathrm{HC}=6$, Wilcoxon test $p=0.43$; Figure 7A,B). This indicates that IL-2 is an essential stimulus for this recently identified Th cell subset in MS. Specificity of this effect was verified by using an isotype control antibody. The overall Th1 and Th17 cells but not GM-CSF co-expressing Th1 and Th17 cells were also suppressed by the anti-IL-12 and by the anti-IL-2 plus anti-IL-12 antibodies in PBMC from both 
HC and MS patients (Figure S6). Altogether, these data indicate dysregulation of pro-inflammatory cytokines in MS and suggests reduced TGF- $\beta$ in MS as a potential common mechanism.

\section{Healthy}

A

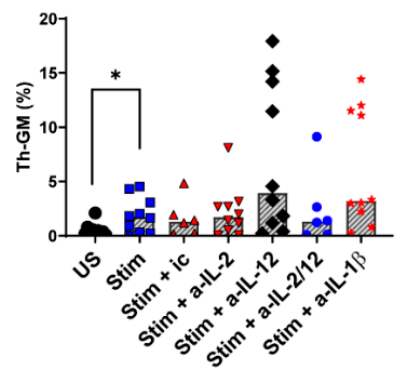

C

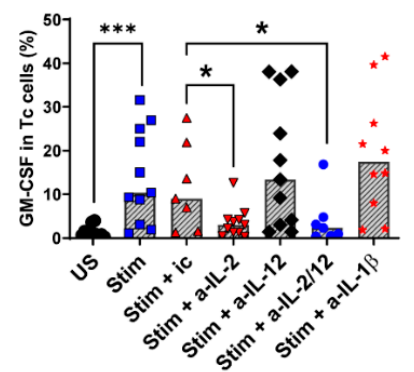

E

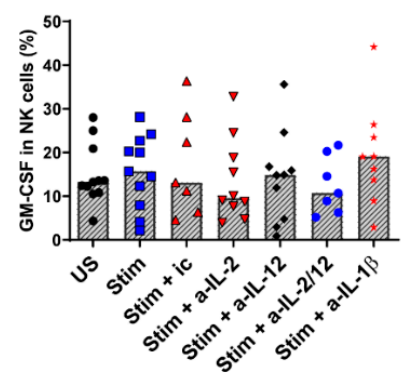

G

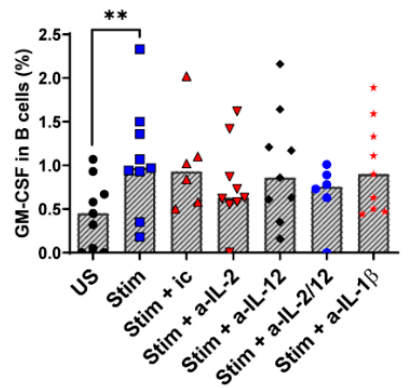

\section{MS}

B

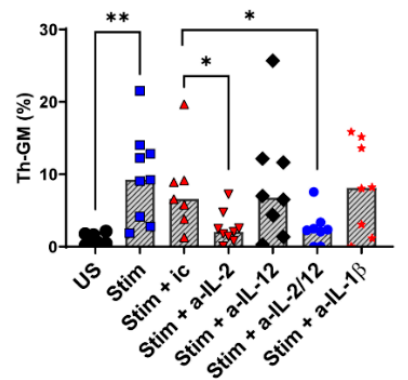

D

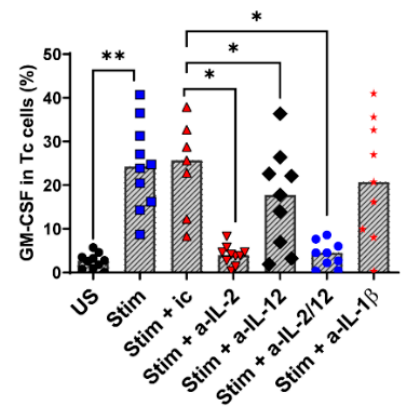

$\mathbf{F}$

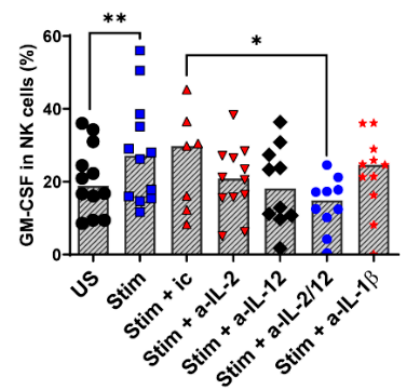

H

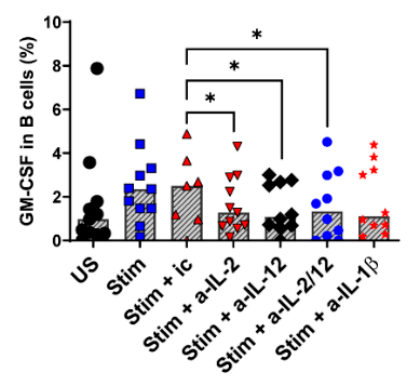

Figure 7. Effects of anti-cytokine antibodies on the frequency of GM-CSF-expressing PBMC subsets: Frozen/thawed cultured PBMC from healthy controls and MS patients were cultured either unstimulated (US) or stimulated (Stim) with anti-CD3/anti-CD28 for 5 days. Stimulated cells were left with or without adding one of the antibodies to block the following cytokine (a-cytokine: cytokine antibody): IL-2, IL-12, IL-2 + IL-12 (IL-2/IL-12), and IL-1 $\beta$. In addition, stimulated cells were cultured with an antibody isotype control (ic) as the controls. The left panel represents healthy control results, and the right panel represents MS patient results. (A,B) Th-GM percentage; (C,D) percentage of cells expressing GM-CSF in Tc cells; $(\mathbf{E}, \mathbf{F})$ percentage of cells expressing GM-CSF in NK cells; $(\mathbf{G}, \mathbf{H})$ percentage of cells expressing GM-CSF in B cells. ${ }^{*} p<0.05^{* *} p<0.01$; and ${ }^{* * *} p<0.001$. Bars represent medians. 
3.7. Blocking IL-2 and IL-12 In Vitro Reduces the Frequency of Tc, NK, and B Cells Expressing GM-CSF in Stimulated PBMC from MS Patients

We examined the percentage of Tc cells, NK cells, and B cells expressing GM-CSF in cultured and stimulated PBMC. We found that blocking IL-12 significantly reduced the frequency of Tc cells expressing GM-CSF in MS (Wilcoxon test: MS $n=7, p=0.046$; HC $n=7, p=0.57$; Figure 7C,D). In addition, blocking IL-2 + IL-12 significantly reduced the percentage of NK cells expressing GM-CSF in MS (Wilcoxon test: MS $n=10, p=0.01 ; \mathrm{HC} n=7, p=0.53$; Figure 7E,F). Moreover, we found that blocking either IL-2, IL-12, or both together significantly reduced the percentage of B cells expressing GM-CSF in MS but not in HC (Wilcoxon test, MS $n=7$, blocking IL-2 $p=0.031$; blocking IL-12 $p=0.046$, blocking IL-2 + IL-12 $p=0.031$; Wilcoxon test, HC $n=6$, blocking IL-2 $p=0.06$; blocking IL-12 $p=0.56$; blocking IL-2 + IL-12 $p=0.093$; Figure 7G,H). These results suggest dysregulation of GM-CSF across several immune cell types.

3.8. Th-GM Cells Differentiated In Vitro from Naïve CD4 T Cells Are More Frequent in Samples from MS Patients, and Exogenous IL-2 Increases Their Proportion Further

It was shown that IL-2 and IL-7 may play a role in the differentiation of Th-GM cells from naïve CD4 T cells $[17,20]$. We aimed to determine whether the same pathways govern naïve CD4 T cell differentiation into Th-GM cells in humans and to investigate the frequency of these cells in MS patients compared to HC. Figure S7 shows the gating strategy for the analysis of these cells. We found that some naïve CD4 T cells differentiate into Th-GM after 7 days of stimulation with anti-CD3/anti-CD28. The frequency of Th-GM cells was higher in MS patients than in HCs (Mann-Whitney test $p=0.015$; Figure 8C). When IL-2 was added to the medium, a higher proportion of Th-GM cells was observed in MS patients (Mann-Whitney $p=0.007$ ), while IL-7 and the combination of IL-2 and IL-7 did not further affect the frequency of these cells. There was no detectible IL-3 expression after 7 days of culturing naïve CD4 T cells (results not shown). These findings complement the above results in PBMC, where neutralizing endogenously IL-2 in vitro reduced the frequency of Th-GM cells in MS patients but not in HCs. In these experiments, the above cytokines did not show differential effects on the expression of IFN- $\gamma$ between MS and HC (Figure 8D,E, respectively).

A

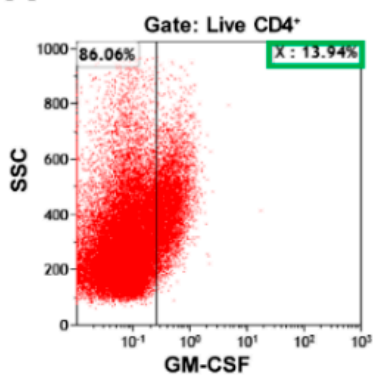

C

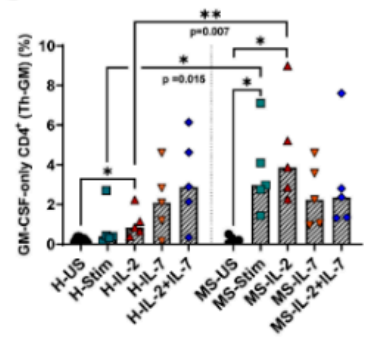

B

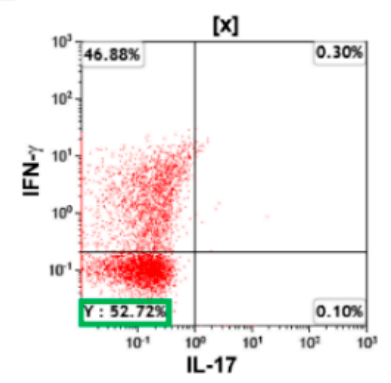

E
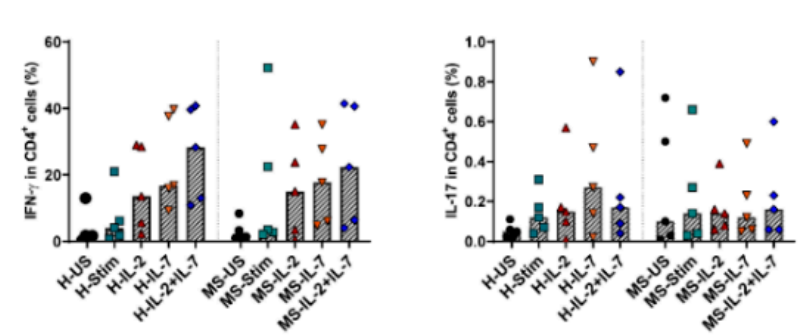

Figure 8. Frequency of cytokine-producing $\mathrm{CD}^{+} \mathrm{T}$ cells differentiated from naïve CD4 T cells in MS patient samples. Representative plots are shown in this figure. Freshly isolated ( $\geq 90 \%$ pure) naïve CD4 
T cells $\left(\mathrm{CD}^{+} \mathrm{CD}^{+} 5 \mathrm{RA}^{+}\right.$) from healthy controls (H) and MS patients (MS) were left either unstimulated (US) or stimulated (Stim) with anti-CD3/anti-CD28 alone or with IL-2 and/or IL-7 for 7 days. (A) Identification of GM-CSF-expressing naïve CD4 cells (labelled as population X). (B) Using gating on population X, GM-CSF-only expressing cells were identified (labelled as population $Y$ ). The frequency of Th-GM cells among CD4 T cells was calculated according to the equation Th-GM $(\%)=X \times Y \times 100 \%$ (where $X$ and $Y$ are expressed as decimal values). (C) cumulative data from healthy controls and MS patients showing the frequency of Th-GM cells among CD4 T cells. (D,E) cumulative data from healthy controls and MS patients showing the frequency of IFN- $\gamma^{-}$and IL-17-producing CD4 T cells, respectively. Bars are medians. ${ }^{*} p<0.05$ and ${ }^{* *} p<0.01$.

\section{Discussion}

In MS, multiple neuroantigens are involved and the pathogenesis is not fully understood [34,35]. However, the common pathological process is the activation of inflammatory pathways, which involves antigen-specific $\mathrm{T}$ cells that stimulate more general immune cell activation and inflammation. Here, immune cells were stimulated to mimic antigen-specific activation and $\mathrm{T}$ cell receptor engagement plus co-stimulation, using antibodies against CD3 and CD28. Our aim was to determine if T cell-specific stimulation upregulates GM-CSF in T cells and in other immune cell types in the mixed PBMC; to investigate whether this upregulation is higher in MS; to identify factors (perhaps in addition to the known role of IL-2) that may be involved in this upregulation; and to determine whether immunoregulatory factors like TGF- $\beta$ are produced in lower amounts in MS under these conditions.

To test the hypothesis that imbalance between pro-and anti-inflammatory factors, here focusing on GM-CSF in MS, is T cell driven, the CD3/anti-CD28 stimulation is relevant. It mimics antigen-specific activation of $\mathrm{T}$ cells [36,37]. This stimulation induced substantial and consistent cytokine production in PBMC; similar protocols were previously used by our groups and others in studies of this subject [19,22]. We found that activated Th1 and Th17 cells express GM-CSF and that the frequency of GM-CSF-expressing Th1 cells is higher in PBMC from MS patients than HC. This is associated with higher levels of Th1 inducing IL-12 in PBMC from MS patients. Higher IL-2 levels detected in this work and the association of IL-2R polymorphisms reported in MS with higher production of GM-CSF by $\mathrm{T}$ cells [22] may contribute to this finding. We also detected GM-CSF-only expressing Th cells and found their frequency to be higher in MS. These cells (called Th-GM cells) being increased in MS are likely to have a pathogenic role, supported by their expansion in the CNS in MS together with CXCR4 [24]. These cells also express integrin $\alpha 4 \beta 1$ (very late antigen-4, VLA-4) and probably have different migration properties than the other Th subsets [20-24]. Of note, cells named here Th-GM (for simplicity) were shown in this study to express GM-CSF but not IFN- $\gamma$, IL-17, or IL-3 (to compare them to the murine counterpart described by Sheng and colleagues [17]); we have not tested the coexpression of other cytokines that can coexist with GM-CSF [24] such as IL-9, IL-22, IL-21, etc.

We also show that GM-CSF is expressed at higher frequency by in vitro stimulated Th and Tc cells in MS patients when compared to HC. This is consistent with recent studies [19,22] and indicates that GM-CSF has a crucial role in autoimmune inflammation. We found that GM-CSF is more highly expressed by monocytes from MS patients in mixed PBMC upon T cell stimulation.

Our results also demonstrate a higher proportion of GM-CSF-expressing B cells in PBMC from MS patients after in vitro stimulation. This is consistent with the findings of a seminal study performed on $B$ cells after their isolation and stimulation with either PMA/I or CD40L ${ }^{+}$anti-IgM [38]. Our results suggest that $\mathrm{T}$ cells can stimulate B cell GM-CSF production.

We also show a higher frequency of NK cells expressing GM-CSF in PBMC from MS patients when compared to healthy controls after in vitro T-cell dependent stimulation. A previous study has found an increase in NK cells in PBMC during the remission stage of MS. These cells were of the NK2 subtype exerting anti-inflammatory actions including the suppression of Th1 responses [39]. It has been reported that peripheral NK2 and NK1 cells produce similar amounts of GM-CSF [40]. The elevation of the percentage of GM-CSF-expressing NK cells in MS may indicate a potential pathogenic role. 
Indirect stimulation of NK cells with a T cell stimulus (anti-CD3/anti-CD28) induced a higher frequency of GM-CSF-expressing NK cells in MS. Here, investigating GM-CSF expression in isolated NK cells using stimuli known to induce high GM-CSF concentrations in NK cells [28], we show similar GM-CSF expression in MS patients and HC. This indicates that the factors that are more abundant in MS and that induce GM-CSF in MS NK cells are dependent on T cell activation.

In this study, the levels of GM-CSF, IL-2, IL-12, and IL- $1 \beta$ were elevated, and the levels of TGF- $\beta 1$ were reduced in the culture supernatants of in vitro stimulated PBMC from MS patients.

Our study confirms the role of IL-2 in the upregulation of GM-CSF in MS already shown in a previous study [22]. Complementing that study where exogenous IL-2 stimulated Th expression of GM-CSF to higher levels in MS, here, we show that anti-IL-2 suppresses it and not only in Th cells but also other cell types. Although that study did not identify the Th subsets with increased GM-CSF production, it found that GM-CSF and IFN- $\gamma$ expression (but not IL-17) was increased in MS, raising the possibility that these GM-CSF-expressing cells are Th1 cells and the newly identified Th cell subset (Th-GM cells) but not Th17 cells. Subsequent studies by the same group using single cell sequencing identified those MS-relevant cells as pathogenic CXCR4 ${ }^{+}$Th cells. Our results are also consistent with the findings of a recent study showing that GM-CSF but not IFN- $\gamma$ was induced by IL- 2 to be expressed by Th cells. These cells were distinct from the classical Th1 or Th17 subsets and had different migration properties [20,23]. We hereby confirm and further describe the GM-CSF-non-Th1-nonTh17-producing Th cell subset that is increased in MS; IL-2 potentially plays an important role in their differentiation.

We also found that blocking IL-12 significantly reduced the frequency of Tc cells expressing GM-CSF in MS patients but not in healthy controls. IL-12 is involved in the generation of Tc cells [33]. It synergizes with IL-2 to increase GM-CSF expression [33]. It was shown that IL-12A and IL-12B genetic polymorphisms are genetic risk factors for MS [32], which may lead to increased IL-12-induced GM-CSF expression.

The results of this work show a reduction in the frequency of $\mathrm{CD}^{-} \mathrm{CD} 56^{+} \mathrm{PBMC}$ (NK cells) expressing GM-CSF after blocking both IL-2 and IL-12 in PBMC from MS patients after anti-CD3/anti-CD28 stimulation but not in those from healthy controls. These results complement previous reports that IL-2 and IL-12 induce NK cell cytotoxicity and GM-CSF production [41-44]. The differential effects between stimulated cells from MS and controls may again be attributed to the known MS-associated polymorphisms in the IL-12 subunits, IL-12R, and IL-2R genes, as previously demonstrated for T cell-derived GM-CSF [22,32].

Here, the blockade of IL-2 significantly reduced the percentage of GM-CSF-expressing B cells in stimulated PBMC from MS patients but not healthy controls. IL-2R- $\alpha$ (CD25) is expressed on immature [45] B cells, and IL-2 induces B cell proliferation and differentiation into plasma cells [46-49]. This is probably the first report of the relation between IL-2 and GM-CSF expression in B cells. On the other hand, as cytokine expression may reflect lymphocyte activation [50], reduced activation and proliferation of B cells by blocking IL-2 may have resulted in reduced GM-CSF expression. This effect was statistically significant in MS patients, possibly because of higher IL-2 levels in MS patients, or because the same MS-associated IL-2R polymorphism governs GM-CSF production by B cells as in T cells. GM-CSF may exert an autocrine effect increasing B cell survival [51], which may be pathogenic.

We show that blocking IL-12 reduces GM-CSF expression by B cells. While IL-12 induces GM-CSF expression in T cells [52], this was not explored thoroughly in B cells. A previous study has shown IL-12 to induce B cell differentiation into a distinct subset similar to Th1 cells [53]. We found significantly higher IL-12 levels in supernatants of stimulated PBMC from MS patients compared to HCs and MS patients. Our results show for the first time that IL-12 is nonredundant for GM-CSF expression by B cells in mixed immune cell populations stimulated with a T cell stimulus in MS patients compared to HC. This may be explained by concentration-related effects of IL-12 on GM-CSF expression by B cells in MS or by polymorphisms in IL-12 or IL-12R, which are genetic risk factors of MS [54,55].

The upregulation of GM-CSF across cell lineages may reflect a higher state of activation of immune cells from people with MS compared to healthy controls. Our previous studies have shown increased 
activation markers such as CD69 and CD154 on T cells from MS patients compared to healthy controls, either ex vivo without stimulation or after in vitro stimulation as in the current paper [56]. This likely reflects genetically determined enhanced IL-2 responsiveness in MS. In view of this, we have not corrected our intracellular cytokine staining findings by activation marker expression, in particular since basal unstimulated production of GM-CSF usually tends to be minimal. Although attributing the upregulation of GM-CSF merely to higher T cell activation in MS does not reduce the significance of the finding, we postulate a more specific effect. First, the same upregulation was not seen for other proinflammatory cytokines in this study. Secondly, other activating stimuli do not differentially induce GM-CSF in cells from people with MS or healthy control volunteers. Third, both the enhanced activation of GM-CSF across immune cell types and the higher immune activation state may result from immune dysregulation, e.g., reduced TGF- $\beta$. The reduction in TGF- $\beta$ is a key finding of our study.

TGF- $\beta$ is an anti-inflammatory cytokine that inhibits the differentiation, proliferation, and functioning of Th1 and Th2 cells. However, it is involved in Th17 differentiation in the presence of IL-6. It is also involved in the differentiation of Treg in the presence of IL-2. TGF- $\beta$ also supresses NK and B cell functioning and maturation [57,58]. Our finding of lower TGF- $\beta$ levels in PBMC culture supernatants of MS patients is relevant and provides a plausible mechanism for the upregulation of GM-CSF across immune cell lineages along with elevated pro-inflammatory cytokines in MS. Low TGF- $\beta$ may result in numerical or functional decreases of Treg in MS patients, which inhibit GM-CSF expression by immune cells. Other studies have shown contradicting findings in terms of serum levels of TGF- $\beta$ in MS, being elevated in some [59] and reduced in others [60]. Our study is different in that it tests culture supernatants but not serum levels.

We also examined whether the Th-GM cells differentiated from naïve CD4 T cells as identified in mice [17] are also present in humans and whether there are differences between MS and HC. Therefore, IL-7 was used for differentiation and IL-2 was used alone or with IL-7. Of note, adding IL-2 (10 ng/mL) to CD4 memory $\mathrm{T}$ cells for 5 days significantly increases GM-CSF-producing Th cells without affecting IFN- $\gamma$ or IL-17 expression [20]. Our results suggest that anti-CD3/anti-CD28-stimulated naïve CD4 T cells probably differentiate to Th-GM cells. The frequency of Th-GM cells was higher in stimulated Th cells from MS patients than HC. IL-2 increased the frequency of Th-GM in cultured Th cells from MS patients. These results add to the evidence for the role of IL-2 in GM-CSF production and its increase in MS.

\section{Conclusions}

In conclusion, multiple immune cell types in a mixture that reflects peripheral blood composition show increased pro-inflammatory cytokine GM-CSF production upon in vitro stimulation with $\mathrm{T}$ cell stimuli in PBMC from patients with MS. This may have wider implications, as it is likely that a similar dysregulation is present in other inflammatory autoimmune diseases, where GM-CSF has been implicated [61]. The addition of a positive control group with other inflammatory diseases in parallel to the present MS group would have strengthened our results. From a therapeutic perspective, it was the promising results of GM-CSF blockade in rheumatoid arthritis (reviewed in [62]) that encouraged investigation of a similar approach in MS [63]. For example, a human monoclonal antibody was shown to be safe and well tolerated in phase I clinical trials in MS and rheumatoid arthritis [64-66]. Thus, targeting dysregulated GM-CSF or its receptor is a potentially effective and safe addition to the therapeutic armamentarium in MS and possibly other autoimmune diseases.

Supplementary Materials: Supplementary Materials are available online at http:/www.mdpi.com/2227-9059/8/7/ 226/s1.

Author Contributions: All the authors mentioned have significant contribution to this research. Their main contributions were as follows: conceptualization, J.A., B.G., and C.S.C.; methodology, J.A., E.M., N.F., S.L.C., and D.O.; software, J.A., D.O., S.L.C., and M.A.; validation, J.A., D.O., and C.S.C.; formal analysis, J.A. and D.O.; investigation, J.A.; resources, A.S., R.T., B.G., and C.S.C.; data curation, J.A., D.O., I.S., C.S.C.; writing-original draft preparation, J.A.; writing-review and editing, J.A., B.G., N.F., S.L.C., and C.S.C.; visualization, J.A. and C.S.C.; supervision, B.G. and C.S.C.; reading of the manuscript and feedback, all authors; project administration, 
J.A. and C.S.C.; funding acquisition, J.A., R.T., B.G., and C.S.C. All authors have read and agreed to the published version of the manuscript.

Funding: We thank Human Capacity Development Programme (HCDP)/Kurdistan Region of Iraq and Hawler Medical University/Erbil-Iraq for supporting Aram during these studies. The study was also supported in part by the Forman-Hardy Charitable Trust via the University of Nottingham.

Acknowledgments: Special thanks for the Neurology staff and the MS Clinical Trials Unit at the University of Nottingham, Queen's Medical Centre, for their help in collecting blood from participants.

Conflicts of Interest: R.T. has received support for the attendance of clinical and research conferences from Biogen, Teva UK, and Sanofi Genzyme; personal compensation for consultancy from Sanofi Genzyme; and unrestricted research grant from Sanofi Genzyme, outside the submitted work. B.G. has received personal compensation for consultancy from Merck, Roche, Biogen, and Teva UK; unrestricted research grants from Biogen Idec, Merck, Bayer Healthcare, Teva UK, Novartis, and Sanofi Genzyme; and support for the attendance of clinical and research conferences from Biogen, Merck, Bayer Healthcare, Teva UK, Novartis, and Sanofi Genzyme. C.S.C. has received support for the attendance of clinical and research conferences from Biogen, Novartis, Teva Pharmaceuticals and personal fees or other funding from Biogen, Novartis, Merck Serono, Teva Pharmaceuticals. He was the chief investigator and received research support and consultancy fees from Morphosys for the phase I trial of MOR103 in MS.

\section{References}

1. Compston, A.; Coles, A. Multiple sclerosis. Lancet 2008, 372, 1502-1517. [CrossRef]

2. Haegert, D.G. Multiple sclerosis: A disorder of altered T-cell homeostasis. Mult. Scler. Int. 2011, $2011,461304$. [CrossRef] [PubMed]

3. Desai, R.A.; Davies, A.L.; Tachrount, M.; Kasti, M.; Laulund, F.; Golay, X.; Smith, K.J. Cause and prevention of demyelination in a model multiple sclerosis lesion. Ann. Neurol. 2016. [CrossRef] [PubMed]

4. Handman, E.; Burgess, A.W. Stimulation by granulocyte-macrophage colony-stimulating factor of Leishmania tropica killing by macrophages. J. Immunol. 1979, 122, 1134-1137.

5. Hamilton, J.A.; Stanley, E.R.; Burgess, A.W.; Shadduck, R.K. Stimulation of macrophage plasminogen activator activity by colony-stimulating factors. J. Cell Physiol. 1980, 103, 435-445. [CrossRef]

6. Whetton, A.D.; Dexter, T.M. Myeloid haemopoietic growth factors. Biochim. Biophys. Acta 1989, 989, 111-132. [CrossRef]

7. Stanley, E.; Lieschke, G.J.; Grail, D.; Metcalf, D.; Hodgson, G.; Gall, J.A.; Maher, D.W.; Cebon, J.; Sinickas, V.; Dunn, A.R. Granulocyte/macrophage colony-stimulating factor-deficient mice show no major perturbation of hematopoiesis but develop a characteristic pulmonary pathology. Proc. Natl. Acad Sci. USA 1994, 91, 5592-5596. [CrossRef]

8. Sawada, M.; Itoh, Y.; Suzumura, A.; Marunouchi, T. Expression of cytokine receptors in cultured neuronal and glial cells. Neurosci. Lett. 1993, 160, 131-134. [CrossRef]

9. Ponomarev, E.D.; Shriver, L.P.; Maresz, K.; Pedras-Vasconcelos, J.; Verthelyi, D.; Dittel, B.N. GM-CSF production by autoreactive $\mathrm{T}$ cells is required for the activation of microglial cells and the onset of experimental autoimmune encephalomyelitis. J. Immunol. 2007, 178, 39-48. [CrossRef] [PubMed]

10. Kroenke, M.A.; Chensue, S.W.; Segal, B.M. EAE mediated by a non-IFN-gamma/non-IL-17 pathway. Eur. J. Immunol. 2010, 40, 2340-2348. [CrossRef]

11. Codarri, L.; Gyulveszi, G.; Tosevski, V.; Hesske, L.; Fontana, A.; Magnenat, L.; Suter, T.; Becher, B. RORgammat drives production of the cytokine GM-CSF in helper T cells, which is essential for the effector phase of autoimmune neuroinflammation. Nat. Immunol. 2011, 12, 560-567. [CrossRef] [PubMed]

12. El-Behi, M.; Ciric, B.; Dai, H.; Yan, Y.; Cullimore, M.; Safavi, F.; Zhang, G.X.; Dittel, B.N.; Rostami, A. The encephalitogenicity of $\mathrm{T}(\mathrm{H}) 17$ cells is dependent on IL-1- and IL-23-induced production of the cytokine GM-CSF. Nat. Immunol. 2011, 12, 568-575. [CrossRef] [PubMed]

13. McQualter, J.L.; Darwiche, R.; Ewing, C.; Onuki, M.; Kay, T.W.; Hamilton, J.A.; Reid, H.H.; Bernard, C.C. Granulocyte macrophage colony-stimulating factor: A new putative therapeutic target in multiple sclerosis. J. Exp. Med. 2001, 194, 873-882. [CrossRef] [PubMed]

14. Marusic, S.; Miyashiro, J.S.; Douhan, J., 3rd; Konz, R.F.; Xuan, D.; Pelker, J.W.; Ling, V.; Leonard, J.P.; Jacobs, K.A. Local delivery of granulocyte macrophage colony-stimulating factor by retrovirally transduced antigen-specific $\mathrm{T}$ cells leads to severe, chronic experimental autoimmune encephalomyelitis in mice. Neurosci. Lett. 2002, 332, 185-189. [CrossRef] 
15. Duncker, P.C.; Stoolman, J.S.; Huber, A.K.; Segal, B.M. GM-CSF Promotes Chronic Disability in Experimental Autoimmune Encephalomyelitis by Altering the Composition of Central Nervous System-Infiltrating Cells, but Is Dispensable for Disease Induction. J. Immunol. 2018, 200, 966-973. [CrossRef]

16. Komuczki, J.; Tuzlak, S.; Friebel, E.; Hartwig, T.; Spath, S.; Rosenstiel, P.; Waisman, A.; Opitz, L.; Oukka, M.; Schreiner, B.; et al. Fate-Mapping of GM-CSF Expression Identifies a Discrete Subset of Inflammation-Driving T Helper Cells Regulated by Cytokines IL-23 and IL-1beta. Immunity 2019, 50, 1289-1304 e1286. [CrossRef]

17. Sheng, W.; Yang, F.; Zhou, Y.; Yang, H.; Low, P.Y.; Kemeny, D.M.; Tan, P.; Moh, A.; Kaplan, M.H.; Zhang, Y.; et al. STAT5 programs a distinct subset of GM-CSF-producing $\mathrm{T}$ helper cells that is essential for autoimmune neuroinflammation. Cell Res. 2014, 24, 1387-1402. [CrossRef]

18. Carrieri, P.B.; Provitera, V.; De Rosa, T.; Tartaglia, G.; Gorga, F.; Perrella, O. Profile of cerebrospinal fluid and serum cytokines in patients with relapsing-remitting multiple sclerosis: A correlation with clinical activity. Immunopharmacol. Immunotoxicol. 1998, 20,373-382. [CrossRef]

19. Rasouli, J.; Ciric, B.; Imitola, J.; Gonnella, P.; Hwang, D.; Mahajan, K.; Mari, E.R.; Safavi, F.; Leist, T.P.; Zhang, G.X.; et al. Expression of GM-CSF in T Cells Is Increased in Multiple Sclerosis and Suppressed by IFN-beta Therapy. J. Immunol. 2015, 194, 5085-5093. [CrossRef]

20. Noster, R.; Riedel, R.; Mashreghi, M.F.; Radbruch, H.; Harms, L.; Haftmann, C.; Chang, H.D.; Radbruch, A.; Zielinski, C.E. IL-17 and GM-CSF expression are antagonistically regulated by human $\mathrm{T}$ helper cells. Sci. Transl. Med. 2014, 6, 241ra280. [CrossRef]

21. Imitola, J.; Rasouli, J.; Watanabe, F.; Mahajan, K.; Sharan, A.D.; Ciric, B.; Zhang, G.X.; Rostami, A. Elevated expression of granulocyte-macrophage colony-stimulating factor receptor in multiple sclerosis lesions. J. Neuroimmunol. 2018, 317, 45-54. [CrossRef]

22. Hartmann, F.J.; Khademi, M.; Aram, J.; Ammann, S.; Kockum, I.; Constantinescu, C.; Gran, B.; Piehl, F.; Olsson, T.; Codarri, L.; et al. Multiple sclerosis-associated IL2RA polymorphism controls GM-CSF production in human TH cells. Nat. Commun. 2014, 5, 5056. [CrossRef] [PubMed]

23. Restorick, S.M.; Durant, L.; Kalra, S.; Hassan-Smith, G.; Rathbone, E.; Douglas, M.R.; Curnow, S.J. CCR6(+) Th cells in the cerebrospinal fluid of persons with multiple sclerosis are dominated by pathogenic non-classic Th1 cells and GM-CSF-only-secreting Th cells. Brain Behav. Immun. 2017, 64, 71-79. [CrossRef] [PubMed]

24. Galli, E.; Hartmann, F.J.; Schreiner, B.; Ingelfinger, F.; Arvaniti, E.; Diebold, M.; Mrdjen, D.; van der Meer, F.; Krieg, C.; Nimer, F.A.; et al. GM-CSF and CXCR4 define a T helper cell signature in multiple sclerosis. Nat. Med. 2019, 25, 1290-1300. [CrossRef] [PubMed]

25. Grishkan, I.V.; Ntranos, A.; Calabresi, P.A.; Gocke, A.R. Helper T cells down-regulate CD4 expression upon chronic stimulation giving rise to double-negative T cells. Cell Immunol. 2013, 284, 68-74. [CrossRef]

26. Pelchen-Matthews, A.; Parsons, I.J.; Marsh, M. Phorbol ester-induced downregulation of CD4 is a multistep process involving dissociation from p56lck, increased association with clathrin-coated pits, and altered endosomal sorting. J. Exp. Med. 1993, 178, 1209-1222. [CrossRef]

27. Mendes, R.; Bromelow, K.V.; Westby, M.; Galea-Lauri, J.; Smith, I.E.; O’Brien, M.E.; Souberbielle, B.E. Flow cytometric visualisation of cytokine production by CD3-CD56+ NK cells and CD3+CD56+ NK-T cells in whole blood. Cytometry 2000, 39, 72-78. [CrossRef]

28. Cooper, M.A.; Fehniger, T.A.; Turner, S.C.; Chen, K.S.; Ghaheri, B.A.; Ghayur, T.; Carson, W.E.; Caligiuri, M.A. Human natural killer cells: A unique innate immunoregulatory role for the CD56(bright) subset. Blood 2001, 97, 3146-3151. [CrossRef]

29. Barr, T.A.; Shen, P.; Brown, S.; Lampropoulou, V.; Roch, T.; Lawrie, S.; Fan, B.; O'Connor, R.A.; Anderton, S.M.; Bar-Or, A.; et al. B cell depletion therapy ameliorates autoimmune disease through ablation of IL-6-producing B cells. J. Exp. Med. 2012, 209, 1001-1010. [CrossRef]

30. Duhen, T.; Campbell, D.J. IL-1beta promotes the differentiation of polyfunctional human CCR6+CXCR3+ Th1/17 cells that are specific for pathogenic and commensal microbes. J. Immunol. 2014, 193, 120-129. [CrossRef]

31. Hashimoto, S.I.; Komuro, I.; Yamada, M.; Akagawa, K.S. IL-10 inhibits granulocyte-macrophage colony-stimulating factor-dependent human monocyte survival at the early stage of the culture and inhibits the generation of macrophages. J. Immunol. 2001, 167, 3619-3625. [CrossRef] [PubMed]

32. Sawcer, S.; Hellenthal, G.; Pirinen, M.; Spencer, C.C.; Patsopoulos, N.A.; Moutsianas, L.; Dilthey, A.; Su, Z.; Freeman, C.; Hunt, S.E.; et al. Genetic risk and a primary role for cell-mediated immune mechanisms in multiple sclerosis. Nature 2011, 476, 214-219. [CrossRef] [PubMed] 
33. Trinchieri, G. Interleukin-12: A proinflammatory cytokine with immunoregulatory functions that bridge innate resistance and antigen-specific adaptive immunity. Annu. Rev. Immunol. 1995, 13, 251-276. [CrossRef] [PubMed]

34. Hohlfeld, R.; Dornmair, K.; Meinl, E.; Wekerle, H. The search for the target antigens of multiple sclerosis, part 1: Autoreactive CD4+ T lymphocytes as pathogenic effectors and therapeutic targets. Lancet Neurol. 2016, 15, 198-209. [CrossRef]

35. Hohlfeld, R.; Dornmair, K.; Meinl, E.; Wekerle, H. The search for the target antigens of multiple sclerosis, part 2: CD8+ T cells, B cells, and antibodies in the focus of reverse-translational research. Lancet Neurol. 2016, 15, 317-331. [CrossRef]

36. Groh, V.; Bruhl, A.; El-Gabalawy, H.; Nelson, J.L.; Spies, T. Stimulation of T cell autoreactivity by anomalous expression of NKG2D and its MIC ligands in rheumatoid arthritis. Proc. Natl. Acad. Sci. USA 2003, 100, 9452-9457. [CrossRef]

37. Reynolds, J.; Tam, F.W.; Chandraker, A.; Smith, J.; Karkar, A.M.; Cross, J.; Peach, R.; Sayegh, M.H.; Pusey, C.D. CD28-B7 blockade prevents the development of experimental autoimmune glomerulonephritis. J. Clin. Investig. 2000, 105, 643-651. [CrossRef]

38. Li, R.; Rezk, A.; Miyazaki, Y.; Hilgenberg, E.; Touil, H.; Shen, P.; Moore, C.S.; Michel, L.; Althekair, F.; Rajasekharan, S.; et al. Proinflammatory GM-CSF-producing B cells in multiple sclerosis and B cell depletion therapy. Sci. Transl. Med. 2015, 7, 310ra166. [CrossRef]

39. Takahashi, K.; Miyake, S.; Kondo, T.; Terao, K.; Hatakenaka, M.; Hashimoto, S.; Yamamura, T. Natural killer type 2 bias in remission of multiple sclerosis. J. Clin. Investig. 2001, 107, R23-R29. [CrossRef]

40. Peritt, D.; Robertson, S.; Gri, G.; Showe, L.; Aste-Amezaga, M.; Trinchieri, G. Differentiation of human NK cells into NK1 and NK2 subsets. J. Immunol. 1998, 161, 5821-5824.

41. Lehmann, C.; Zeis, M.; Uharek, L. Activation of natural killer cells with interleukin 2 (IL-2) and IL-12 increases perforin binding and subsequent lysis of tumour cells. Br. J. Haematol. 2001, 114, 660-665. [CrossRef] [PubMed]

42. Parihar, R.; Dierksheide, J.; Hu, Y.; Carson, W.E. IL-12 enhances the natural killer cell cytokine response to Ab-coated tumor cells. J. Clin. Investig. 2002, 110, 983-992. [CrossRef] [PubMed]

43. Leong, J.W.; Chase, J.M.; Romee, R.; Schneider, S.E.; Sullivan, R.P.; Cooper, M.A.; Fehniger, T.A. Preactivation with IL-12, IL-15, and IL-18 induces CD25 and a functional high-affinity IL-2 receptor on human cytokine-induced memory-like natural killer cells. Biol. Blood Marrow Transpl. 2014, 20, 463-473. [CrossRef] [PubMed]

44. Boyman, O.; Sprent, J. The role of interleukin-2 during homeostasis and activation of the immune system. Nat. Rev. Immunol. 2012, 12, 180-190. [CrossRef]

45. Amu, S.; Brisslert, M. Phenotype and function of CD25-expressing B lymphocytes isolated from human umbilical cord blood. Clin. Dev. Immunol. 2011, 2011, 481948. [CrossRef]

46. Mingari, M.C.; Gerosa, F.; Carra, G.; Accolla, R.S.; Moretta, A.; Zubler, R.H.; Waldmann, T.A.; Moretta, L. Human interleukin-2 promotes proliferation of activated B cells via surface receptors similar to those of activated T cells. Nature 1984, 312, 641-643. [CrossRef]

47. Nakagawa, T.; Hirano, T.; Nakagawa, N.; Yoshizaki, K.; Kishimoto, T. Effect of recombinant IL 2 and gamma-IFN on proliferation and differentiation of human B cells. J. Immunol. 1985, 134, 959-966.

48. Miyawaki, T.; Suzuki, T.; Butler, J.L.; Cooper, M.D. Interleukin-2 effects on human B cells activated in vivo. J. Clin. Immunol. 1987, 7, 277-287. [CrossRef]

49. Le Gallou, S.; Caron, G.; Delaloy, C.; Rossille, D.; Tarte, K.; Fest, T. IL-2 requirement for human plasma cell generation: Coupling differentiation and proliferation by enhancing MAPK-ERK signaling. J. Immunol. 2012, 189, 161-173. [CrossRef] [PubMed]

50. Ai, W.; Li, H.; Song, N.; Li, L.; Chen, H. Optimal method to stimulate cytokine production and its use in immunotoxicity assessment. Int. J. Environ. Res. Public Health 2013, 10, 3834-3842. [CrossRef]

51. Harris, R.J.; Pettitt, A.R.; Schmutz, C.; Sherrington, P.D.; Zuzel, M.; Cawley, J.C.; Griffiths, S.D. Granulocyte-macrophage colony-stimulating factor as an autocrine survival factor for mature normal and malignant B lymphocytes. J. Immunol. 2000, 164, 3887-3893. [CrossRef] [PubMed]

52. Trinchieri, G. Interleukin-12: A cytokine produced by antigen-presenting cells with immunoregulatory functions in the generation of T-helper cells type 1 and cytotoxic lymphocytes. Blood 1994, 84, 4008-4027. [CrossRef] 
53. Durali, D.; de Goer de Herve, M.G.; Giron-Michel, J.; Azzarone, B.; Delfraissy, J.F.; Taoufik, Y. In human B cells, IL-12 triggers a cascade of molecular events similar to Th1 commitment. Blood 2003, 102, 4084-4089. [CrossRef] [PubMed]

54. Shokrgozar, M.A.; Sarial, S.; Amirzargar, A.; Shokri, F.; Rezaei, N.; Arjang, Z.; Radfar, J.; Yousefi-Behzadi, M.; Ali Sahraian, M.; Lotfi, J. IL-2, IFN-gamma, and IL-12 gene polymorphisms and susceptibility to multiple sclerosis. J. Clin. Immunol. 2009, 29, 747-751. [CrossRef]

55. Javan, M.R.; Shahraki, S.; Safa, A.; Zamani, M.R.; Salmaninejad, A.; Aslani, S. An interleukin 12 B single nucleotide polymorphism increases IL-12p40 production and is associated with increased disease susceptibility in patients with relapsing-remitting multiple sclerosis. Neurol Res. 2017, 39, 435-441. [CrossRef]

56. Braitch, M.; Kawabe, K.; Nyirenda, M.; Gilles, L.J.; Robins, R.A.; Gran, B.; Murphy, S.; Showe, L.; Constantinescu, C.S. Expression of activity-dependent neuroprotective protein in the immune system: Possible functions and relevance to multiple sclerosis. Neuroimmunomodulation 2010, 17, 120-125. [CrossRef] [PubMed]

57. Yoshimura, A.; Muto, G. TGF-beta function in immune suppression. Curr. Top Microbiol. Immunol. 2011, 350, 127-147. [CrossRef]

58. Zheng, S.G. Regulatory T cells vs Th17: Differentiation of Th17 versus Treg, are the mutually exclusive? Am. J. Clin. Exp. Immunol. 2013, 2, 94-106.

59. Nicoletti, F.; Di Marco, R.; Patti, F.; Reggio, E.; Nicoletti, A.; Zaccone, P.; Stivala, F.; Meroni, P.L.; Reggio, A. Blood levels of transforming growth factor-beta 1 (TGF-beta1) are elevated in both relapsing remitting and chronic progressive multiple sclerosis (MS) patients and are further augmented by treatment with interferon-beta 1b (IFN-beta1b). Clin. Exp. Immunol. 1998, 113, 96-99. [CrossRef]

60. Rollnik, J.D.; Sindern, E.; Schweppe, C.; Malin, J.P. Biologically active TGF-beta 1 is increased in cerebrospinal fluid while it is reduced in serum in multiple sclerosis patients. Acta Neurol. Scand. 1997, 96, 101-105. [CrossRef]

61. Hamilton, J.A. GM-CSF in inflammation. J. Exp. Med. 2020, 217, 1-16. [CrossRef] [PubMed]

62. Avci, A.B.; Feist, E.; Burmester, G.R. Targeting GM-CSF in rheumatoid arthritis. Clin. Exp. Rheumatol. 2016, 34 (4 Suppl. 98), 39-44.

63. Schottelius, A. The role of GM-CSF in multiple sclerosis. Drug Res. (Stuttg) 2013, 63 (Suppl. 1). [CrossRef] [PubMed]

64. Behrens, F.; Ostergaard, M.; Stoilov, R.; Wiland, P.; Huizinga, T.W.; Berenfus, V.Y.; Tak, P.P.; Vladeva, S.; Rech, J.; Rubbert-Roth, A.; et al. First in Patient Study of Anti-GM-CSF Monoclonal Antibody (MOR103) in Active Rheumatoid Arthritis: Results of a Phase 1b/2a Randomized, Double-Blind, Placebo-Controlled Trial. Arthritis Rheum. 2012, 64, 4171-4172.

65. Constantinescu, C.S.; Asher, A.; Fryze, W.; Kozubski, W.; Wagner, F.; Aram, J.; Tanasescu, R.; Korolkiewicz, R.P.; Dirnberger-Hertweck, M.; Steidl, S.; et al. Randomized phase 1b trial of MOR103, a human antibody to GM-CSF, in multiple sclerosis. Neurol Neuroimmunol. Neuroinflamm. 2015, 2, e117. [CrossRef]

66. Behrens, F.; Tak, P.P.; Ostergaard, M.; Stoilov, R.; Wiland, P.; Huizinga, T.W.; Berenfus, V.Y.; Vladeva, S.; Rech, J.; Rubbert-Roth, A.; et al. MOR103, a human monoclonal antibody to granulocyte-macrophage colony-stimulating factor, in the treatment of patients with moderate rheumatoid arthritis: Results of a phase Ib/IIa randomised, double-blind, placebo-controlled, dose-escalation trial. Ann. Rheum Dis. 2015, 74, 1058-1064. [CrossRef]

(C) 2020 by the authors. Licensee MDPI, Basel, Switzerland. This article is an open access article distributed under the terms and conditions of the Creative Commons Attribution (CC BY) license (http://creativecommons.org/licenses/by/4.0/). 